\title{
Conversion of clearcut beech coppices into high forests with continuous cover: A case study in central Italy
}

\author{
Orazio Ciancio ${ }^{a}$, Piermaria Corona ${ }^{b, *}$, Andrea Lamonaca ${ }^{b}$, \\ Luigi Portoghesi ${ }^{\mathrm{b}}$, Davide Travaglini ${ }^{\mathrm{a}}$ \\ a Dipartimento di Scienze e Tecnologie Ambientali Forestali, Università di Firenze, \\ via San Bonaventura 13, 50145 Firenze, Italy \\ ${ }^{\mathrm{b}}$ Dipartimento di Scienze dell'Ambiente Forestale e delle sue Risorse, Università della Tuscia, \\ via San Camillo de Lellis, 01100 Viterbo, Italy
}

\begin{abstract}
Converting coppices into high forests with continuous cover has often been established during the last decades as a management goal in hilly and mountainous Mediterranean areas to attenuate the negative effects that frequent clearcutting may have on soil, landscape and biodiversity conservation. The silvicultural tool usually adopted for this purpose is the gradual thinning of sprouts during the long span of time required to complete the conversion, that also allows the owner to keep harvesting some wood. This research compared the effects of various thinning intensities (three treatments plus control) on the stand growth and structure of a beech coppice with standards. The optimal density after thinning was assessed by expressing mean tree spacing as a function of main stand attributes like stand height and stand dbh. This system was preferred to the empirical evaluation of the percentage of basal area to be removed in order to give forest managers general reference guidelines to adapt to the varying environments of the Mediterranean mountains. Results confirmed that the positive effects of thinning on mean stem volume is due more to the higher diameter increment than to different height growth. The acceleration of crown growth in the thinned plots allowed canopy closure to be achieved 13 years after thinning. This reduced the negative effects of the opening of the stand overlayer and the elimination of most suppressed trees on soil protection. Under the conditions examined, the best thinning intensity proved to be a stand density $20 \%$ lower than normal prescribed by the yield tables elaborated for beech high forests in Central and Southern Italy.
\end{abstract}

(C) 2005 Elsevier B.V. All rights reserved.

Keywords: Coppice; Conversion to high forest; Thinning; Relative spacing; Continuous cover forestry; Fagus sylvatica

\section{Introduction}

Coppice is a silvicultural system that is still widespread over European Mediterranean countries where it covers an area of about 23 million of hectares (UN/ECE-FAO, 2000). In Italy, coppice area accounts for about 3.9 million hectares located along the lower slopes of the Alps and all along the Appennine range from the coast to the upper mountain zone. The majority are coppices with standards, that is even-aged stands with 40 150 trees of two to three times the rotation age released at the coppicing time. Only small areas are covered by selection coppices (ceduo a sterzo) or compound coppices, which are a mixture of coppice and high forest. Oaks (Quercus cerris L., $Q$. pubescens Willd, $Q$. ilex $\mathrm{L}$.), sweet chestnut (Castanea sativa

\footnotetext{
* Corresponding author. Tel.: +390761 357425; fax: +39 0761357389 . E-mail address: piermaria.corona@unitus.it (P. Corona).
}

Miller) and beech (Fagus sylvatica L.) are the most common species in coppices and often form pure stands. Tree composition usually reflects the natural vegetation, even though the growth and density of many hardwoods (e.g. maples, ashes, rowans, hornbeams) have been limited because they are considered low quality fuelwood.

The success of coppice forestry can be explained considering the advantages it gives to forest owners: simplicity of management, ease and rapidity of natural regeneration, fast growth of the new stand and, thus, shorter rotation and more frequent income than high forests. Nevertheless, coppices with standards under a regular felling regime have some negative effects. Frequent clearcutting over large (up to 10-20 ha) areas on steep slopes exposes soil to erosion. Skidding harvested trees with tractors may remove the humus horizon and exposes the A horizon to the action of the intense rainfalls which characterize the Mediterranean climate (Corona et al., 1996). The opening of regularly shaped clearfelling areas can also have a dramatic 


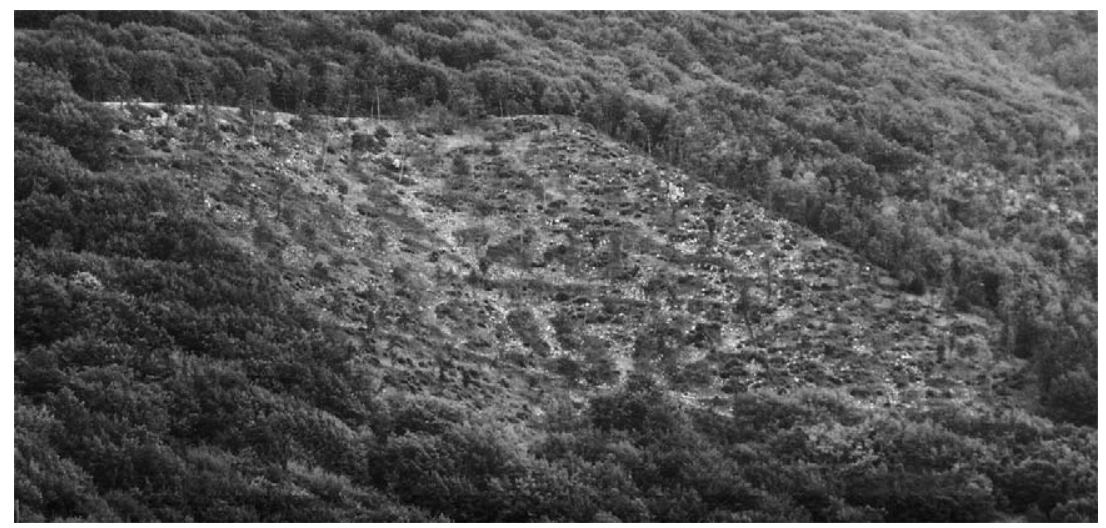

Fig. 1. Example of a typical clearcut in a beech coppice with standards on Central Italy mountains.

impact on the landscape (Fig. 1). Coppicing has different effects on biodiversity, in relation to the ecological component considered and the reference time scale (Goldsmith, 1992; Deconchat, 1999). It modifies the distribution and features of habitats and maintains prevalently monolayer stands and low levels of dead biomass. The food offered by coppices does not generally constitute a limiting factor for the spread of ungulates, but frequent harvesting may have negative consequences on bird nesting (Ciancio and Nocentini, 2004).

Therefore, in order to maintain highly productive chestnut and oak coppices with standards on hilly areas, more restrictive silvicultural guidelines were adopted in many Italian regions, which impose lower extension and irregular shape of clearcut areas as well as longer minimum rotation (Portoghesi, 1998). New silvicultural techniques have also been experimented to foster the sustainable management of coppices (e.g. European Commission and Regione Umbria, 2002).

In the upper mountain belt of the Appennine range, where beech coppices with standards are mainly located, depopulation and changes in the socio-economical conditions over the last 60 years led to a pronounced drop in local demand for small size timber, firewood and charcoal. As a consequences, many coppices have been almost completely abandoned due to lack of active management and no monitoring of their natural evolution. Over the same period, mountain forests were considered increasingly important as a defence against natural hazards, for biodiversity conservation, for the development of recreational and tourist activities, for the protection of water resources and so on. These processes are common to other European Mediterranean countries (e.g. Ducrey, 1992; Serrada et al., 1998a).

In this socio-economic context, the conversion of coppices with standards into high forests is considered one of the best management alternatives both for the public good and as an improvement for the owners' future revenue by the yield of larger size trees. Such a management option can be framed as a process from a silvicultural system based on clearcutting (the beech coppice with standards) towards a silvicultural system based on continuous cover (the beech high stand to be managed by group shelterwood or selection systems at the end of the conversion).
Since Italian coppices vary greatly in terms of species composition, stand structure and management types, the systems and methods for conversion to high forests cannot be generalized: great flexibility is required (Ciancio and Nocentini, 2004). The abandoning of coppicing alone leads to the slow natural evolution of the stands towards the high forest, but more active management can foster stand dynamics and the achievement of the final desired structure, reducing the risk of damage from fire, windthrows and parasites attacks, and still allowing the exploitation of a certain amount of wood during the conversion period.

In beech coppices with standards, conversion is usually carried out by gradually thinning the stand (i.e. the so called balivage intensif, according to the classic French tradition: e.g. see Hubert, 1981) in order to prepare, in the shortest possible time, suitable microsite conditions for regeneration from seeds. The best sprouts in terms of vigour, size and shape are favoured by early thinnings, which cull the weaker trees. Later interventions can also interest the dominant layer. The new high stand starts growing under cover of the released sprouts or after the regeneration fellings, which can be carried out by group shelterwood or selection cutting according to the forest structure desired. On the whole, conversion of beech coppices in mountainous areas is quite a long process. The transformation from a coppice stand at the rotation age into an adult high forest can last up to 150 years, depending on site fertility (Ciancio and Nocentini, 2004).

Coppices growing in harsh climates produce many crooked and branched stems which makes it difficult to adopt the selection of future trees as a thinning criteria. Therefore, the basic question to face concerns the coppice density after each thinning which is usually established using empirical criteria, such as the release of the best shoot on each stump, or the harvest of a percentage of the initial basal area according to the local site and stand conditions (Giannini and Piussi, 1976; Ducrey, 1992). Such criteria have been used in experimental trials aiming at evaluating the response of oak coppice stands to different thinning intensity (Amorini et al., 1998; Serrada et al., 1998b; Cañellas et al., 1998, 2004; Ciancio and Nocentini, 2004). But, with the exception of some rare cases, these experiments are not yet complete and it is not possible to derive general criteria to provide forest managers with operational 
reference guidelines in the very different situations they encounter in the varying environment, which characterizes the Mediterranean mountains.

The following research tries a different approach using an innovative method for modulating thinning intensity by relevant stand attributes. The efficacy of such a method was tested in a beech coppice with standards, comparing the response of the stand to three different thinning intensities.

\section{Material and methods}

\subsection{Experimental site}

The study area is located along the northern facing slope of Mount Nuria at an altitude of $1500 \mathrm{~m}$ a.s.l., in the western part of Latium, Central Italy $\left(42^{\circ} 22^{\prime} \mathrm{N}\right.$ latitude, $13^{\circ} 04^{\prime} \mathrm{E}$ longitude).

Mount Nuria is part of the original calcareous formation of the Central Appennines and consists of cretaceous limestone with flint inclusions. Soils belong to the "terre rosse" (Mediterranean red soils) type with clay-lime texture and are rather deep and fertile in less sloping zones, becoming much more shallow when ground inclination increases and at the highest altitude. Mount Nuria vegetation comprises beech forest and brushwood with Juniperus alpina, Vaccinium myrtillus and Arctostaphylos uva-ursi of the upper mountain and subalpine belts. Annual precipitation exceeds $1600 \mathrm{~mm}$, with no summer drought; mean annual temperature is of $5.5^{\circ} \mathrm{C}$ with severe winter cold (mean temperatures are less than $10{ }^{\circ} \mathrm{C}$ for 8 months).

The experimentation took place in a 53-year old beech coppice with standards, which covers about 142 ha. The coppice age, 23 years older than the usual rotation age of beech coppices in Central Italy, allowed to start the conversion without needing to wait to suppress the undesiderable resprouting potential of the stumps. The forest is owned by the local Municipality: although firewood still has an active market locally, the owner decided to start the conversion in order to foster change towards a management system based on high forest with continuous cover, under a multifunctional (recreation, landscape, soil conservation) perspective.

\subsection{Basic framework}

Objective definition of optimal stand density after thinning for plantations and even-aged high forests has usually been based on either model (yield table) prescriptions or the use of indexes like the mean distance between stems (dist), worked out as a percentage (relative spacing $=$ rs) of stand height $(h)$ (e.g. see the Hart-Becking index, Becking, 1953):

dist $=\mathrm{rs} \times h$

In this research both methods have been taken into consideration. In Italy there are very few yield tables for beech high forests and those that do exist are based on local site conditions and very specific thinning regimes. However, they offer some

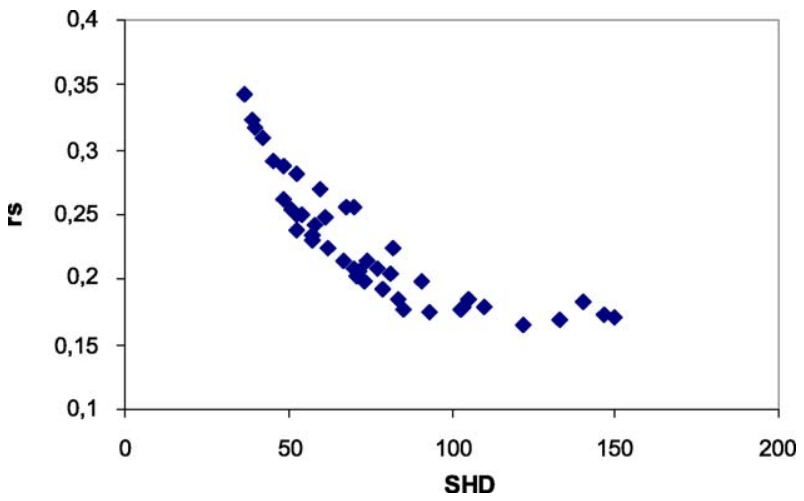

Fig. 2. Scatterplot of prescribed relative spacing (rs) vs. the ratio between stand height and stand dbh (SHD) from the yield tables elaborated for the managed even-aged beech high forests of Central and Southern Italy.

general indication on how prescribed stand stocking varies as a function of average stand sizes ( $\mathrm{dbh}$ and height). From the analysis of the yield tables elaborated for Central and Southern Italy beech forests, the following close inverse correlation between the prescribed (so called, normal) relative spacing ( $\mathrm{rs}=\mathrm{dist} / h$ ) and the ratio between mean stand height and mean stand dbh (SHD index) was recognized (Fig. 2):

$\mathrm{rs}=0.1+\frac{0.085}{\mathrm{SHD}}$

The rationale of [2] is that in even-aged beech stands the SHD index tends to be correlated to rs since, ceteris paribus, stands with "slimmer" trees, characterized by a high ratio between stem height and dbh, have generally smaller crowns, thus requiring smaller growing space. This relationship is irrespective of site quality as no significant correlation between rs and site index was detected.

Therefore, adopting as a reference the relationships [1] and [2] it is possible to model the theoretical normal spacing of a given stand by the SHD index (e.g. if $\mathrm{SHD}=150$, then dist $=0.16 \times h$; if SHD $=100$ then dist $=0.18 \times h$, and so on). If the actual spacing is lower than normal, then the stand should be thinned. Using a stand inventory data set, the number of stems to be cut in each dbh class can be defined by an iterative algorithm as follows:

1. to calculate rs by Eq. (2) using measured SHD;

2. to simulate the thinning from below in each dbh class up to match the value of dist by Eq. (1);

3. calculate the new SHD and $h$ values for the thinned stand and derive the corresponding new value of rs and dist: if the latter value of dist only differs slightly from that calculated at point 2 , stop the simulation and adopt the simulated thinning intensity for each dbh class; if not, continue the simulation from point 2 .

\subsection{Experimental design}

The experimentation compares three different intensities of thinning from below and the control. In the investigated beech 
coppice, stand density before thinning was over 1.5 times the theoretical normal one (as modelled by Eqs. (1) and (2)), and by thinning it was set:

- 5\% higher than the theoretical normal density (treatment A); - $5 \%$ lower than the theoretical normal density (treatment B); - $20 \%$ lower than theoretical normal density (treatment C).

No thinning was done in the control (treatment D). Each treatment was repeated three times, for a total of 12 (4 treatments $\times 3$ repetitions) on $900 \mathrm{~m}^{2}$ squared plots. Higher thinning intensity was excluded to avoid large gaps in the stand overlayer, which might have accelerated soil erosion on a slope with an average inclination of $45 \%$ by reducing the rainfall interception. Adopting a moderate thinning regime can also limit eventual resprouting from stumps stimulated by the cutting (on such an issue, see, for instance, Amorini et al., 1998).

In 1988 and in 2001 the diameter at breast height (dbh) of all trees above $4.5 \mathrm{~cm}$ in the plots was recorded, and a sample of 30 total tree heights per plot was collected. The topographic position of all the stems within a $30 \mathrm{~m} \times 10 \mathrm{~m}$ transect centered on each sample plot was mapped and tree crown projection measured based on four perpendicular radii in order to evaluate the degree of canopy cover and crown overlapping. The stand profile and the crown projection map of each plot was drawn using the Stand Visualization System program (http://faculty.washington.edu/mcgoy/svs.html).

According to single-factor ANOVA (Zar, 1996), no significant differences in stand volume and mean dbh of shoots and standards among the plots assigned to the different treatments were detected before thinning. On average, 46\%, $53 \%$ and $63 \%$ of the stems were harvested by thinning the plots assigned, respectively, to treatments $\mathrm{A}-\mathrm{C}$. The ratio between the mean volume of the harvested stems and that of all the stems before thinning varies from 0.38 to 0.49 , as typical for thinning from below (Rollison, 1985).

\section{Results}

After 13 years, mortality was, on average, about $8.5 \%$ in the control, whereas in the thinned plots the number of stems only increased slightly in treatment $\mathrm{A}(+5 \%)$ and remained unchanged in treatments $\mathrm{B}$ and $\mathrm{C}$ (Table 1, Fig. 3). Hence, the resprouting from stumps is under control: this is a relevant issue as new sprouts in shade-tolerant species stands, creating an underlayer, can hinder the growth of future sexual

Table 1

Main stand features just after thinning (1988) and 13 years after thinning (2001)

\begin{tabular}{|c|c|c|c|c|c|c|c|c|c|c|}
\hline \multirow[t]{2}{*}{ Treatment } & \multicolumn{2}{|c|}{$\begin{array}{l}\text { Stem number } \\
\left(n \mathrm{ha}^{-1}\right)\end{array}$} & \multicolumn{2}{|c|}{ Basal area $\left(\mathrm{m}^{2} \mathrm{ha}^{-1}\right)$} & \multicolumn{2}{|c|}{$\begin{array}{l}\text { Stand volume } \\
\left(\mathrm{m}^{3} \mathrm{ha}^{-1}\right)\end{array}$} & \multicolumn{2}{|c|}{ Stand dbh $(\mathrm{cm})$} & \multicolumn{2}{|c|}{ Stand height (m) } \\
\hline & 1988 & 2001 & 1988 & 2001 & 1988 & 2001 & 1988 & 2001 & 1988 & 2001 \\
\hline Control & 3848 & 3519 & 39.49 & 45.84 & 338.7 & 438.6 & 11.5 & 13.0 & 12.3 & 14.4 \\
\hline A & 1767 & 1863 & 24.90 & 31.67 & 223.8 & 311.3 & 13.4 & 14.7 & 13.1 & 15.4 \\
\hline B & 1463 & 1459 & 23.43 & 29.19 & 216.1 & 297.6 & 14.3 & 15.9 & 13.5 & 15.8 \\
\hline $\mathrm{C}$ & 1300 & 1322 & 19.12 & 26.32 & 174.6 & 270.3 & 13.6 & 15.9 & 13.2 & 15.4 \\
\hline
\end{tabular}
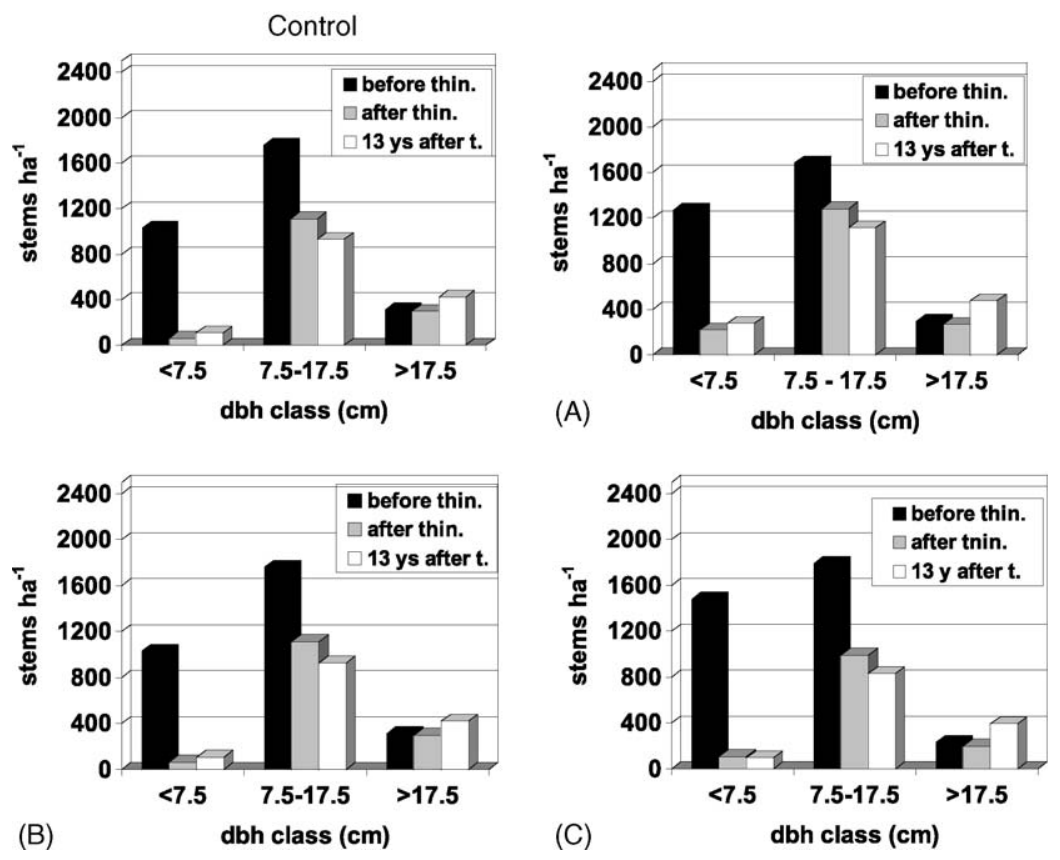

Fig. 3. Average number of stems in dbh classes before, just after and 13 years after thinning in the plots assigned to the four considered treatments. 
Table 2

Effect of thinning intensities on selected stand parameters (13 years after thinning), as evaluated by single-factor ANOVA (treatments with different letters are statistically different at $p=0.05$ )

\begin{tabular}{llllll}
\hline Treatment & $\begin{array}{l}\text { Stand volume } \\
\text { growth rate }(\%)\end{array}$ & $\begin{array}{l}\text { Mean stem } \\
\text { volume }\left(\mathrm{m}^{3}\right)\end{array}$ & $\begin{array}{l}\text { Canopy cover } \\
\text { index }^{\mathrm{a}}\end{array}$ & $\begin{array}{l}\text { Crown overlapping } \\
\text { index }^{\mathrm{b}}\end{array}$ & $\begin{array}{l}\text { Ratio of actual to } \\
\text { normal stem density }\end{array}$ \\
\hline Control & $2.3 \mathrm{a}$ & $0.12 \mathrm{a}$ & 0.7 & $1.77 \mathrm{a}$ & $2.3 \mathrm{a}$ \\
$\mathrm{A}$ & $3.0 \mathrm{ab}$ & $0.17 \mathrm{ab}$ & 0.7 & $0.97 \mathrm{~b}$ & $1.3 \mathrm{~b}$ \\
$\mathrm{~B}$ & $2.9 \mathrm{ab}$ & $0.20 \mathrm{~b}$ & 0.7 & $0.81 \mathrm{~b}$ & $1.3 \mathrm{~b}$ \\
$\mathrm{C}$ & $4.2 \mathrm{~b}$ & $0.20 \mathrm{~b}$ & 0.6 & $0.33 \mathrm{c}$ & $1.1 \mathrm{~b}$ \\
\hline
\end{tabular}

${ }^{\text {a }}$ Ratio of canopy cover projection and sample plot area.

b Ratio of the sum of tree crown overlaps and sample plot area.
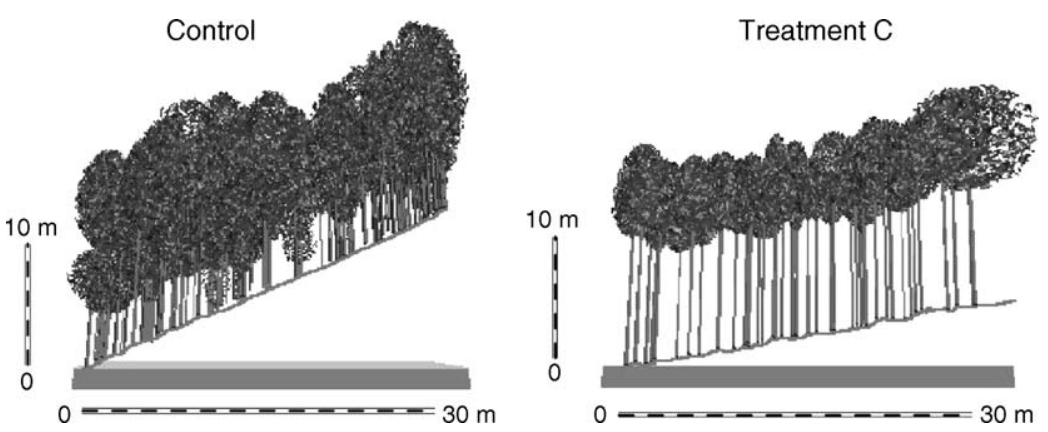

Fig. 4. Examples of stand profile within the transects established in the control plot and in the $\mathrm{C}$-treatment plot, of the same age, 13 year after thinning. The thinning from below simplified the stand profile. However, the faster growth of trees will allow to anticipate the execution of regeneration cutting, reducing the duration of the conversion: then, adopting shelterwood or selection cutting silvicultural systems the forest will assume a more diverse structure.

regeneration and require one more intervention to clear them. The absence of resprouting can be correlated to the low intensity, in absolute terms, of thinning as only from $18 \%$ to $29 \%$ of basal area was extracted.

In term of stand volume, $45-80 \mathrm{~m}^{3}$ per hectare were harvested. The latter figure corresponds to the thinning of highest intensity (treatment $\mathrm{C}$ ) and equals the average amount of wood, which can be obtained in Italy from coppicing a beech stand growing on medium quality sites at the usual rotation age of 25-30 years. The thinning can therefore be economically viable although most of the wood harvested was only suitable as firewood given the small size of the thinned trees.

The effects of thinning after 13 years, as evaluated by singlefactor ANOVA, are shown in Table 2. The significant differences in terms of stand volume percent increment indicates that suppressed trees affected, to a certain extent, the growth of dominant ones, and therefore that competition before thinning was both asymmetric and two-sided (sensu Brand and Magnussen, 1988). This was true even for plots subjected to the lowest intensity thinning (treatment A).

The mean stem volume is now significantly larger in the thinned plots than in the control. This is due to the diameter growth more than the height growth: thinned plots had higher stand dbh but mean stand height was quite similar to control (Table 1), even if the mean annual increment of both attributes did not show significant differences between treatments.

The effects of thinning on canopy cover and crown overlapping degree were of particular interest. As to the first attribute, there was no significant differences between treatments 13 years after thinning. The elongation of tree branches filled the gaps opened by thinning even in the most intensively thinned plots. The significant differences of crown overlapping among treatments meant that stand profile of thinned plots, although continuous, tended to remain monolayered even many years after the cut of suppressed trees (Fig. 4) as a consequence of the beneficial lack of the resprouting.

Thirteen years after thinning the canopy was closed again even in the most intensively thinned plots, where, on the other hand, the degree of overlapping was significantly less, and hence the light use is more effective in relative terms. Indeed, after thinning the ratio between actual and theoretical normal stem density increased steadily, and now is more than one again, even in the most intensively thinned plots. The average value of such a ratio was significantly different between treatments only in the case of the control (Table 2).

\section{Discussion and conclusion}

The thinning from below intensity (extraction of $30 \%$ of basal area at the most) applied in the beech coppices to be converted into high forest showed a positive effect on volume growth rate and diameter increment and led to stands with fewer but larger trees. The decrease of stocking did not affect height growth of released trees, thus the higher mean stem volume was due to the crown enlargement, which allowed a higher diameter growth. The different response of height compared to dbh in thinned coppices was also reported by Cañellas et al. (1998, 2004) for oak coppices. This is probably due to the growth of epicormic branches as a consequence of higher light intensity, 
which reaches the underlayer after canopy opening by thinning, as observed by Ducrey (1992) too.

The acceleration of crown growth in the thinned plots compared with the unthinned ones allowed canopy closure to be achieved 13 years after thinning. This reduced the negative effects of the opening of the stand overlayer and the elimination of most suppressed trees on soil protection even in the case of heavy thinning, and has positive consequences on future seed production. Abundant dissemination plays a key role because the conversion of coppices into high forests can be fully achieved when sexual regeneration initiates under the gradually decreasing canopy cover.

The system proposed to assess optimal stocking after thinning as a function of main stand attributes like stand height and stand dbh is promising and should be tested with different species composition and site conditions. The recommended thinning intensity for the beech coppices of Mount Nuria should clearly be that corresponding to treatment $\mathrm{C}$, hence $20 \%$ lower than the theoretical normal density (as modelled by Eqs. (1) and (2)), in order to distance sufficiently over time subsequent thinnings and yield a quantity of wood able at least to pay the cost of harvesting. Adopting this intensity, in little more than 10 years it is possible to achieve canopy closure again and larger volume of mean stem, accelerating the process, which leads to the final goal of sexual regeneration without seriously disturbing the environment, at least under site and silvicultural conditions similar to those here investigated.

Converting beech coppices into high forest through gradual thinning of sprouts is an effective step down the road to silvicultural systems characterized by continuous forest cover. In mountainous areas, this type of management can guarantee both public and private interests. The cessation of clearcutting and the changes in stand structure allows to improve social, landscape and naturalistic functions of the forest which can even justify public subsidies to finance the first interventions, when necessary. However, very few studies can be found in the international literature concerning the conversion of clearcut beech coppices to high stands: this shortcoming could merit future investigation.

\section{Acknowledgements}

The research, carried out in equal parts by the Authors, was partially funded by the Italian Ministry for Agricultural and Forest Policy, under the programme RiSelvItalia (Research Unit 4.2.4, University of Tuscia-DISAFRI). The Authors would like to thank G. Clementi and S. Bollati for their technical support during the fieldwork and two anonymous reviewers who helped to significantly improve the paper.

\section{References}

Amorini, E., Bruschini, S., Cutini, G., Manetti, M.C., 1998. Silvicultural treatment of holm oak (Quercus ilex L.) coppices in southern Sardinia: thinning and related effects on stand structure and canopy cover. Ann. Ist. Sper. Selv. 27, 167-176.

Becking, J.H., 1953. Einige Gesichtpunkte fuer Durchfuehrung von vergleichenden Durchforstungsversuchen in gleichaltrigen Bestanden. In: Proceedings, XIth IUFRO World Congress, Rome, Italy, pp. 580-582.

Brand, D.B., Magnussen, S., 1988. Asymmetric, two-sided competition in evenaged monocultures of red pine. Can. J. For. Res. 18, 901-910.

Cañellas, I., Montero, G., Bachiller, A., 1998. Transformation of quejigo oak (Quercus faginea Lam.) coppice forest into high forest by thinning. Ann. Ist. Sper. Selv 27, 143-147.

Cañellas, I., Del Rio, M., Roig, S., Montero, G., 2004. Growth response to thinning in Quercus pyrenaica Willd. coppice stands in Spanish central mountain. Ann. For. Sci. 61, 243-250.

Ciancio O., Nocentini S., The coppice forest. Silviculture, regulation, management. In: Il bosco ceduo. Selvicoltura, assestamento, gestione. Accademia Italiana di Scienze Forestali, Firenze, Italy, pp. 679-701.

Corona, P., Iovino, F., Lucci, S., 1996. La gestione dei sistemi forestali nella conservazione del suolo. EM-Linea Ecologica 4, 4-15.

Deconchat, M., 1999. Exploitation forestière et biodiversité: exemple dans les forêts fragmentées des coteaux de Gascogne. Thesis 13.01.1999, Paul Sabatier University (Toulouse III), Toulouse, France.

Ducrey, M., 1992. Quelle sylviculture et quel avenir pour les tallis de chene vert (Quercus ilex L.) de la region mediterraneenne francaise. Revue For. Fr. 44, 12-34.

European Commission and Regione Umbria, 2002. Sustainable and multipurpose management of coppices: the Summacop project. Experiences, activities and results. Regione Umbria, Perugia, Italy, pp. 133-170.

Giannini, R., Piussi, P., 1976. La conversion de taillis en futaie. L'expériences italiennes. In: Proceedings, XVI IUFRO World Congress, Oslo, Norway, pp. $388-396$.

Goldsmith, F.B., 1992. Coppicing - a conservation panacea? In: Buckley, G.P. (Ed.), Ecology and Management of Coppice Woodlands. Chapman Hall, London, England, pp. 306-312.

Hubert, M., 1981. Du taillis à la futaie: 8 arguments en faveur du balivage. Forêts de France et Action Forestière 244, 13-17.

Portoghesi, L., 1998. The protective functions of Italian forests. In: Glück, P., Weber, M. (Eds.), Mountain Forestry in Europe-Evaluation of Silvicultural and Policy Means. Publication Series of the Institute for Forest Sector Policy and Economics, 35. Universität für Bodenkultur, Wien, Austria, pp. 49-62.

Rollison, I.J.D., 1985. Thinning control. Forestry Commision Booklet 54. Forestry Commission, England.

Serrada, R., Allué, M., San Miguel, A., 1998a. The coppice system in Spain. Current situation, state of art and major areas to be investigated. Ann. Ist. Sper. Selv 27, 266-275.

Serrada, R., Bravo, A., Sánchez, I., Allué, M., Elena, R., San Miguel, A., 1998b. Conversion into high forest in coppices of Quercus ilex subs. ballota L. in Central region of Iberian Peninsula. Ann. Ist. Sper. Selv 27, 149-160.

UN/ECE-FAO, 2000. Forest resources of Europe, CIS, North America, Australia, Japan and New Zeland. Main Report. Geneva Timber and Forest Study Papers 17, Geneva, Switzerland.

Zar, J.H., 1996. Biostatistical Analysis, 3rd ed. Prentice-Hall International, New York, USA. 